\title{
Notions of work, patrimony and production in the life of the Colón Opera House
}

\author{
Sian Lazar
}

\begin{abstract}
:
This essay discusses a conflict between municipal government, management and workers of Buenos Aires' opera house, the Colón, at the end of the 2000s. A group of workers organised themselves into a 'state of permanent mobilisation' during 2009 to demonstrate against the closure of the opera house for refurbishment and the firing of around 370 of their number. Their argument was that the Colón was being turned from a 'factory theatre' with its own technical and artistic staff into merely a venue for touring productions and retail outlets. The story of the Colón was, then, the story of the 'neoliberalisation' of the Argentine state in miniature: a move from production to subcontracting, with attendant labour flexibilisation, loss of domestic technical skills, business logic, and possibly even destruction of architectural monuments. But, since the conflict was about one of the most celebrated opera houses in the hemisphere, the workers' story was also entangled in questions of elitism, cultural and architectural heritage and the role of (high) cultural institutions in society. In telling the conflict from the perspective of the mobilised workers, I want to explore their notions of work and production. I ask if culture or art can be produced in a material sense, and whether the material metaphor (of being workers in a 'factory theatre') is more than just a means of mobilising people.
\end{abstract}


I arrived a little late for my first demonstration in February 2009, to find a group of people gathered outside the Casa de la Cultura of the City government on the Avenida de Mayo. They surrounded a mat placed on the pavement, on which two ballet dancers danced a pas de deux. Employees of the city government watched the performance from the windows of their offices. At the end the dancers bowed to the audience gathered round them at street level, and to those watching from the windows as if they were in the royal box of a theatre. The duet was followed by impassioned speeches from the head of ATE Capital (the Buenos Aires branch of the Asociación de Trabajadores Estatales, or Association of State Workers), and from one of the members of the ATE junta interna (local council) of the Colón Opera House. Audience members stood round, clapping speakers, holding up their banners declaring for example that 'el Teatro Colón cerrado es estafa al ciudadano' ('a closed Colón defrauds the citizen') - and showing their solidarity with the ATE workers of the Colón. I recognised several ATE activists from a plenary meeting I had attended a few days before, and at which I had heard about this particular act. It culminated in the singing of the national anthem. Since many of the demonstrators consisted of musicians, technicians, opera singers and dancers from possibly the most celebrated opera house of the Southern Hemisphere after Sydney Opera House, this was no ordinary rendition, and the participants sang with evident pride in their collective ability to put on a show of the highest quality. Between then and the end of March, they held similar demonstrations each week, changing the central cultural act, from pas de deux to individual ballet dances, to tango, to trumpet or voice solos, always followed by speeches and the national anthem. The location on the Avenida de Mayo was of course not accidental, as, with the Avenida 9 de Julio, it is one of the two principal axes of the centre of the city of Buenos Aires, running from the Congress Building at one end to the Casa Rosada, or Presidential palace, at the other. Both avenues 
are the sites for many demonstrations and mobilisations, absolutely key to the symbolic economy of protest in Buenos Aires.

The 2009 cycle of protests by the Colón workers began with these highly theatrical performances but quickly became extremely heterodox. After the declaration of a 'state of permanent mobilisation' during February 2009, the workers engaged in a wide-ranging series of actions to protest the closure of the opera house for refurbishment and what they saw as the firing of around 370 of their number (see below for details). Those actions ranged from traditional forms of protest such as marches, public assemblies, leafleting, lobbying members of the legislature, press conferences, the initiation of legal cases to more theatrical displays and performances, such as the acts described above, a mock funeral mourning the 'death of culture', and a music festival. They occurred throughout 2009, at varying levels of intensity; and at the time of writing (September 2014) there has not been a definitive resolution of the conflict. In 2010 the refurbished theatre was reopened to the public, and the firings have stayed in place but are being challenged in the courts. Conflict over these and similar questions re-emerged over the course of subsequent years as part of the ebb and flow common to union struggle.

In 2009, the ATE-Teatro Colón junta interna used the demonstrations to keep their colleagues and other members of their union apprised of the situation at the opera house and to pressure the municipal government on a number of fronts. The backdrop to their complaint was the refurbishment of the building begun in earnest in at the end of $2006^{1}$. The Colón employees had nowhere to work, and when the 2009 season began they had to

\footnotetext{
${ }^{1}$ Refurbishment activities began in 2005, but the theatre was closed for major refurbishment works in October 2006.
} 
rehearse in different venues across the city, building scenery etc in other workshops, ready to put on a very limited season of performances in venues that were significantly inferior to the Colón itself. Meanwhile, there were in addition elements of a more conventional labour dispute: in early 2009, the new management of the opera house announced their intention to reduce the number of permanent employees by a third. So a number of the workers at retirement age were - according to them - being forced to retire against their will; younger people who had been employed on temporary contracts were facing the non-renewal of their contract; and, by the beginning of April, approximately 450 employees remained without any work allocated to them for that year. About 280 of those subsequently received formal notice that they would be transferred to other parts of the municipal government, away from the opera house; and around 90 of those on temporary contracts had been told they would be moved to employment within the health sector of the city government ${ }^{2}$.

In interviews and speeches during protest acts and assemblies, union activists placed this dispute as part of a much longer story of the gradual destruction of the Colón as a particular kind of cultural institution, something they summarised as a move from a 'teatro factoría' (factory theatre) or 'teatro de producción' (production theatre) into a 'sala de alquiler' (room for hire). For them, this was inherently a story of neoliberalisation, a process they were suffering in common with the rest of the Argentine state sector. The refurbishment of the opera house was intimately tied to the attempts to reduce the number of employees on the books through retirements and then transferrals. Both were equally long-standing processes of 'vaciamiento', or 'emptying' of their workplace, which was also the Argentine

\footnotetext{
${ }^{2}$ See 'El verdadero conflicto del Teatro Colón (de lo que nadie quiere hablar)' http://habituesdelteatrocolon.files.wordpress.com/2011/03/el-verdadero-conflicto-del-teatro-colc3b3nactualizado.pdf. Accessed 08.03.2012.
} 
state, as well as of destruction of an important part of Argentine national patrimony. In this article, I explore these various elements to examine the nature of cultural production as state employment, within a context of 'neoliberal' attitudes to both.

My argument is that the story of the Colón is the story of the 'neoliberalisation' of the Argentine state in miniature: a move from production to subcontracting, with attendant labour flexibilisation, loss of domestic technical skills, imposition of business logic, and possibly even destruction of architectural monuments. It exposes some of the connections between changing conditions of work and urban space under broadly neoliberal regimes. But, since the conflict was located in one of the most celebrated opera houses in the hemisphere, the workers' story was also entangled in questions of elitism, cultural and architectural heritage and the role of (high) cultural institutions in society. In telling the conflict from the perspective of the mobilised workers, I hope to explore their notions of work, production and cultural patrimony; as well as to examine how the nature of production shapes possibilities for labour mobilisation in various ways.

Unionism and public sector work: continuity and change in the 1990s and 2000s

My field research with a group of 'mobilised workers' of the Colón took place as part of a comparative research project that explores trade unionism, organisational practices and subjectivity among state employees in Buenos Aires. There are several unions of state employees in Argentina, although at the level of municipal government, the two largest and most influential are SUTECBA (Sindicato Único de Trabajadores Estatales de la Ciudad de Buenos Aires, Unique Union of State Workers for the City of Buenos Aires) and ATE 
(Asociación de Trabajadores del Estado). The mobilised workers of the Colón who are the focus of this article were mostly members of ATE, led by its junta interna, its representative body in the Theatre; although some were members of the rival municipal workers' union, SUTECBA, and others were not affiliated to any union ${ }^{3}$. The story of unionisation is complex, not least because of the rivalry between traditional peronist unionism and more leftist or autonomist strands. As I discuss elsewhere (Lazar 2015a), ATE activists have a strong discourse differentiating themselves from the traditional peronist unions such as SUTECBA, and the Colón junta interna is no exception. ATE activists tend to argue that they are part of a more horizontal, democratic and oppositional tendency within unionism, and often accuse the more traditional unions of corruption, 'verticalism' and co-optation by the state (Lazar 2015a). Prior to the 1990s, ATE was only available to employees of the national Federal government, but with President Menem's decentralisation policies, national institutions such as hospitals and schools were moved to provincial government, and so unions previously available only to employees of the national government were able to seek affiliates within local government. A small group of Colón workers seized this opportunity to affiliate with what was to their minds the more oppositional and democratic union. However, the leading group of the mobilised Colón workers was careful to publically represent their struggle as deriving from the needs of the theatre workers as a whole, not those affiliated to ATE in particular. These workers included scenery technicians and maintenance people, administrators, musicians, singers and dancers, although, as I discuss later, their identity as 'worker' was highly complex and contested.

\footnotetext{
${ }^{3}$ The workers of the municipal government can choose which union to belong to, or whether to belong to any union at all. SUTECBA is dominant in the city government, partly because it is the official Peronist union, and has historically been the one with whom the employers negotiate, partly because it controls the city workers' obra social - health insurance scheme. It is usually the case that membership of both the union and the obra social confers extra benefits above being just a member of the obra social.
} 
I came to the Colón conflict through fieldwork with ATE Capital, the branch of ATE that mobilises state employees who work in the city of Buenos Aires, whether they work for the national or city governments. I heard about the demonstration mentioned above at an assembly of ATE Capital, and so went along. From there, and over a period of about seven months initially in 2009, I joined demonstrations, attended assemblies at the theatre, in the streets and at the workshops. I attended press conferences and festivals of support, and conducted long interviews with some of the mobilised workers, in cafes and in their homes. I returned in 2011 and 2012, conducting a follow up interview with one of the main leaders, and attending another press conference; I have also followed the conflict via email and Facebook. I interviewed four members of the Colón ATE junta interna at length, and one member of SUTECBA. I chose unionist activists deliberately, as my overarching research project investigates union activism among state employees, and draws on ethnographic research over 11 months in 2009 and 2012 and on short research trips in 2011, 2013 and 2014 (see Lazar 2012; Lazar 2015a; Lazar 2015b). As a foreign scholar, I presented myself as one who needs to learn about the local situation, who was interested in unionist activism generally and in the specifics of the Colón situation in particular, as a conflict that crystallised a number of the problems confronted by state unionism at the time. One informant in particular, Máximo Parpagnoli, was especially eloquent in interview, speaking at length about the different intellectual, political and ethical aspects of how the opera house has been managed and how it should be managed, what is its role in society, what is or should be the role of the union, and how theatre workers self-identify. 
My interlocutors' ability to protect their employment through union-based mobilisation relied in part on the success of their ability to draw on a material metaphor of being workers in a teatro factoría, which was powerful as a means of mobilising some people but rejected by many others. The production of 'culture' or 'art' is an example of immaterial labour as defined by Hardt and Negri in Multitude (2005). They argue that 'in the final decades of the twentieth century, industrial labour lost its hegemony and in its stead emerged 'immaterial labor', that is labour that creates immaterial products, such as knowledge, information, communication, a relationship, or an emotional response.' (2005: 108). They stress that the labor itself 'remains material - it involves our bodies and brains as all labor does', but 'what is immaterial is its product.' (2005: 109). While one might take issue on an empirical basis with their claim that immaterial labour has replaced industrial labor as the hegemonic form globally, they make a further important point to do with the possibilities of opposition to what they call Empire, but what we could also call unjust relations of production or neoliberalism, depending on specific contexts. Their point is that the prior emphasis on material production over immaterial production has meant that some figures of labor have been excluded from conceptualisations of the working class, and that this exclusion has affected their ability to oppose economic injustice. This is of course an argument that feminists have been making for some time, but Hardt and Negri have not simply substituted 'immaterial labour' for the feminist idea of social reproduction, since their concept of immaterial labour is somewhat wider. It includes labour that produces knowledge and communication as well as affects and relationships beyond those necessary for social reproduction. The products of the Colón are both material and immaterial: scenery and costumes combined with the unique experience of an opera performance, the affective response of the audience, distinction (Bourdieu 1986), 'art' and even excellence itself. In 
studying the conflict between management and workers there, we can explore how the immaterial aspects of production shape labor mobilisation in opposition to neoliberal restructuring of this workplace; a workplace that came to stand in for the Argentine state, or even Argentina itself, in the eyes of its workers.

Unlike some of the other cases in this special issue, the story of the Colón - as told by its workers - was predominantly one of continuity pre- and post- 2001, with the real point of change for them being at some time in the 1990s. Although the pressures towards labor flexibilisation and deformalisation within the state at both national and provincial levels appear to have become more acute around 2000, my informants mostly felt that what was happening in the city government in the late 2000s was a continuation of the neoliberal processes of the 1990s. At that time, openings for formal, permanent work in the state were frozen, and then new state employees increasingly entered through a bewildering variety of temporary contracts, in large part in order to shrink the appearance of spending on the (national) public sector employment. Provincial governments and the government of the City of Buenos Aires took over the running of previously nationally-run schools and hospitals and followed the national government in the move to temporary employment of newlycontracted civil servants and other state employees. Since 2003 , there has been a slight loosening of this tendency at the level of the national government, as most temporarilycontracted workers have been put on more stable (although still not permanent) contracts and some permanent positions have opened up again. However, state employment has become and remains two-tiered: with one group of permanently employed civil servants who can only be dismissed through disciplinary proceedings working alongside a much younger and much more precariously-employed set of employees. 
So, while since 2000 there has been an increase in the numbers of informal or precarious workers within the state, there are a number of important continuities with older - 'nonneoliberal' notions of work in Argentina. Principle among these continuities is the discursive and emotive power still held by the figure of the formal sector worker for many workers today. That is evident in the use of industrial metaphors of production even within one of the most elitist cultural institutions in the country, as this article will show. The figure of the formally-employed, fully-registered worker with a full and fair range of benefits remains extremely powerful as an ideal that state employees think they are entitled to enjoy, and for which they are prepared to fight. There may even have been a resurgence of such ideas in the post-2003 period, as the Kirchner governments allied themselves with the formal-sector trade unions, and traded some benefits for union support, at least until Cristina Fernandez de Kirchner's break in mid-2012 with the leader of the truck drivers' union, Hugo Moyano, who also led the CGT at the time ${ }^{4}$. Thus the fight between neoliberal imperatives of labour flexibilization and older versions of what work or employment is or should be, or between neoliberal businessmen (in the figure of Mauricio Macri, the Head of Government of the City of Buenos Aires) and formal sector trade unions feels in many ways like quite an old fight in the context of this part at least of the Argentinean public sector.

\author{
The Colón building
}

\footnotetext{
${ }^{4}$ The CGT is the Confederación General del Trabajo, the Peronist central union federation. The split between Cristina Fernandez and Hugo Moyano provoked a split within the CGT, to create an oppositional CGT and an officialist one.
} 
The current opera house, located on a whole block next to the central Avenida 9 de Julio, is the second Colón building. From its early days it was dogged by disputes over ownership and questions of corruption and elitism. Plans for the very grand opera house were initially drawn up in the 1880 s, and some initial funds were raised at the time, but the building was eventually only finished in 1908 (Hodge 1979). During the period of construction, its ownership changed from the national government to the city government. The latter has remained in charge to this day, although there is a difference because the Federal Capital City of Buenos Aires was run by a Mayor appointed by the Federal government until 1994 when the city was given autonomous status. It has had an elected Mayor from 1996, often from a different political party from that running the national government ${ }^{5}$. Whether the Colón belongs to the national government or the government of the City of Buenos Aires matters today because the contemporary City government under Mauricio Macri is much more 'neoliberal' than the national Kirchner regimes of 2003-present, but Buenos Aires retains enormous importance and influence nationally because of its population size and because it is the capital city of the country. There are frequently tensions between city and national governments, as Macri positions himself as a potential oppositional presidential candidate in 2015 and maybe beyond. Drawing on his experience as businessman and chair of Boca Juniors football club, Macri has had a clear conservative agenda for the city government of reducing direct state expenditure and integrating market processes into government activity (Forment 2007).

Yet, although owned and run by the City government, one of the most important aspects of the Colón dispute for the workers involved was its status as national cultural patrimony. For

\footnotetext{
${ }^{5}$ The Partido Justicialista, the main Peronist political party, tends to perform poorly with the voters of metropolitan Buenos Aires, even when it is strong nationally.
} 
many theatre employees and patrons, the Colón was one of the few reminders left of Argentina's former glory as an almost European nation in Latin America. From its beginning, the Colón was representative of a project of nation-building that looked to Europe and to European high culture as the model for civilisation (Benzecry 2011; Benzecry 2014). This is of course a complex matter, as it is inextricably linked to the colonialist project of erasing native cultures and peoples as the nation built itself from the $19^{\text {th }}$ century on. The remnants of such notions of civilization and modernity persist in a still hegemonic discourse of identity among many porteños (those who live in Buenos Aires) which leads them to stress their heritage as the children or grandchildren of European immigrants rather than a Latin American identity. Indeed, one of the more painful aspects of the crisis of 2001-2 for many middle and upper middle class porteños was the perceived 'Latinamericanization' of their country that ensued ${ }^{6}$.

The workers of the Colón were very proud that many highly celebrated European composers, singers and dancers had come to their opera house, including Richard Strauss and Enrico Caruso as well as more contemporary stars such as Plácido Domingo and Luciano Pavarotti ${ }^{7}$. At one point in the early $20^{\text {th }}$ Century, operas opened at the Colón only months after they premiered in European countries (Benzecry 2011; Benzecry 2014). During the late $19^{\text {th }}$ and early $20^{\text {th }}$ Centuries, European performers came in part because the Argentine cold season coincided with the low season in Europe: the famous baritone Titta Ruffo once said,

\footnotetext{
${ }^{6}$ These tensions even also feed into rivalries between the federal government and the city government, as one could argue that conservatives like Macri tend to look to Europe and the US rather more so than the national popular project of the Kirchner governments, which have stressed a Latin American identity and emphasised relationships between countries of the Global South.

${ }^{7}$ The official website lists a large number of famous performers and composers to visit the Colón. See http://www.teatrocolon.org.ar/es/index.php?id=historia2 Retrieved 12 January 2012.
} 
probably not entirely accurately, that he had not experienced summer in 18 years (Rosselli 1990: 169) .

They were also attracted by the acoustics of the theatre, an aspect frequently mentioned to me by my informants. This is part of the self-representation of the Colón, whose official website states that it is considered to be one of the best performance venues in the world for its acoustics ${ }^{8}$, but also part of general cultural lore about the Colón (Benzecry 2011: 18). Indeed, as several of my informants told me, an 'American acoustics expert' placed the Colón third in his rank ordering of concert halls according to acoustical quality in audience areas. I later found the book to which they were referring, written by Leo Beranek, a former MIT professor and author of several textbooks on acoustics. His ordering of concert halls is based on interviews and questionnaire surveys with 'conductors, music critics and concert aficionados' (Beranek 2004). Luciano Pavarotti is supposed to have called the acoustics 'perfect'. 9

The famous acoustics were one of the most important concerns that my informants had with respect to the refurbishment of the theatre. Frequently they worried about the effects that making holes in the walls of the building, changing materials, altering fire exits and so on would have on the acoustics. At the time of a number of the interviews, photographs of the refurbishment process were circulating among them via the 'habitués del teatro colón' blog, which showed holes in the walls and other kinds of mistreatment. ${ }^{10}$ It had happened before, when in 1987, a refurbishment scheme that changed some of the internal fittings

\footnotetext{
${ }^{8}$ http://www.teatrocolon.org.ar/es/index.php?id=historia Retrieved 12 January 2012.

9 Karyl Charna Lynn 'Restoration Drama: The Teatro Colón' Opera Now September-October 2010 pp.29-30.

${ }^{10}$ See http://habituesdelteatrocolon.wordpress.com/2009/04/02/fotos-del-31-de-marzo/ Retrieved 12 January 2012.
} 
from wood to metal changed the acoustics of the theatre so that orchestra conductors could no longer hear singers. Worse, for the singer Ricardo Ochoa, as a result of the modifications

'The sound now tends to rise, because above it's like a huge barbeque grill, the sound rises, and from the stage you think you're breaking the theatre but [actually] the sound doesn't project properly into the hall, and moreover, on rising, there's a metallic, ugly sound to the voice.'

[Ricardo Ochoa 25.06.2009]

Some of the workers and other critics of the refurbishment process were worried that the architects put in charge had little experience of such a delicate building as an opera house. When the Colón finally reopened in May 2010, the management were careful to encourage press articles highlighting the fact that the acoustics had been preserved. ${ }^{11}$ Subsequently, this has been confirmed by academic acoustics specialists (Basso, Haedo, and Quintana 2010). That said, Máximo Parpagnoli, one of the leaders of the ATE junta interna and the theatre photographer, argued in early 2012 that it is in fact a public secret that the acoustics have been damaged, probably irreparably: apart from subjective assessments, he pointed to evidence such as the fact that the management have not yet released the details of the comparative acoustics measurements taken before and after the refurbishment, and copied to me a memo sent to the members of the orchestra asking them to arrive early for a

\footnotetext{
${ }^{11}$ E.g. Clarín 7 May 2010 'Probaron que la acústica del Teatro Colón está intacta' http://edant.clarin.com/diario/2010/05/07/laciudad/h-02192467.htm Retrieved 10 January 2012. 'The Teatro Colón rebirth will bring tiers to your eyes', Daily Telegraph, (UK), 26 May 2010, http://www.telegraph.co.uk/culture/music/opera/7750270/The-Teatro-Colon-rebirth-will-bring-tiers-to-youreyes.html Retrieved 12 January 2012.
} 
production in order to attach microphones to their instruments, something unheard of before (personal communication, e-mail 14.3.2012).

During 2009, informants raised other concerns about the refurbishment, such as reduced or inappropriate rehearsal space, or the seeming lack of space in the refurbishment plans for the theatre's extensive archive. Part of the objections to the proposed refurbishment did appear to derive from an innate conservatism, on the basis that the theatre worked well as it was. However, a large part of the problem was a lack of consultation with those who would work in the newly refurbished opera house. A perceived arrogant and unconsultative attitude from the management was only underlined by public statements by the Theatre Director, Pedro Pablo García Caffi, which were quickly condemned by the mobilised workers as dictatorial language. For example, they took particular offense when he said at one meeting that 'the Colón is not an employment insurance scheme that piles people up in the corridors' ${ }^{12}$ Parpagnoli told me that the use of the phrase 'piling up' evoked the disappearances of political opponents during the military dictatorships of 1976-83.

Returning to the building, the act of refurbishment that was of most symbolic importance for the mobilised workers was, however, the opening up of a large space for a 'montacoche', or an elevator for vehicles, containers or large pieces of scenery. They worried about its possible effect on the theatre's acoustics, and about the reduction in space it meant for technical workshops, and they were irritated that the workers themselves had not been consulted about the architectural plans. But mostly they thought that the building of such a large access point could only mean that plans were afoot to reduce the level of 'producción

\footnotetext{
${ }^{12}$ See 'García Caffi: "El Teatro Colón no es un seguro de empleo que apila gente en los pasillos"' Clarín 14 April 2009. At http://edant.clarin.com/diario/2009/04/14/laciudad/h-01897349.htm Retrieved 12 January 2012
} 
propia' (in-house production) within the theatre building itself, or even remove it entirely. This would mean that instead of producing its own operas, the Colón would house operas produced by other production companies, or would subcontract most of the technical elements of an opera production to local workshops, as indeed it had done before 1925 (Hodge 1979; Rosselli 1990).

Repeatedly, informants argued that this would turn the Colón into a 'sala de alquiler' and shopping mall, because part of the refurbishment included enlarging the space for retail outlets within the building. Their arguments against this process varied. Some argued that outsourcing production would make operas more expensive to put on. Máximo Parpagnoli told of a similar process in La Scala, Milan, recounting the following story:

'They produced a similar model, at the technical level, when Milan's La Scala began refurbishment nearly 10 years ago.... La Scala was a theatre like the Colón, which had stable corps [cuerpos estables] and in-house production, its own production done by its own technical workshops that operated within the institution. Before reforming, La Scala liquidated its in-house production, according to the law, that's to say, gave redundancy payments to the workers and finished with its own production. The technical workers of La Scala, what did they do? They formed work cooperatives, of scenery technicians, of machinists, costumiers, shoemakers, and whatever else, and they scattered across Milan and Italy, and they began to work for other places in Europe and for other production companies. When La Scala re-opened its doors, one of the things that the public began to demand were the La Scala production values, not only at the artistic level. So, the director of La Scala ... got into contact with the cooperatives, and today La Scala pays about 5 times more than it paid before for 
each production. And the technicians are delighted, because they work for La Scala as private providers, charging them a fortune!

[MP 04.03.2009]

Others argued simply that the 'producción propia' was a good in itself. Sara Tonazzi, a scenery painter, told of her pride in the Colón and its workshops when others visited:

'Now, one knows people from outside, from La Scala, from Covent Garden, who come and see our workshops, and they say to us 'this is a treasure, because you won't ever get this back, don't ever liquidate it, don't do what we did.'

[ST 10.05.2009]

During assemblies and demonstrations people also on occasion defended the model of a 'teatro de producción' as a source of jobs. They understood that out-sourcing and subcontracting as employment models meant the loss of jobs. This had happened much more acutely elsewhere in the Argentine state, as described in Elana Shever's work on the privatisation of the state oil company YPF (Shever 2012). Their disdain for 'shoppings' (malls) perhaps also implicitly responded to the proliferation of shopping malls in Buenos Aires as emblematic of the high period of consumption during the 1990s (Guano 2002). As several commentators have argued, the development of high end shopping malls was part of a process of the exacerbation of inequality through specific forms of organising urban space, both public and private. This is represented also by the increase in numbers of gated communities ('countries') and the growth of slum neighbourhoods ('villas'); the building of highways directly between wealthy suburbs and the financial centre of the city; and quasiluxury tourist attractions (Gorelik 2011; Guano 2002; Guano 2004; Svampa 2008).

The Colón as public good 
However, by far the most common argument mobilised against the transformation of the Colón into a 'salon de alquiler' or 'shopping' turned on a complex understanding of it as a public good which should not be subjected to (neoliberal) market logic; an argument which at times proved difficult to make because of the association of opera with elitism. From early on, the Colón's finances had relied upon the sale of boxes to wealthy patrons as well as public funds (Hodge 1979). As with other similar institutions globally, it has been difficult to justify that public subsidy throughout the Colón's history. From the beginnings of opera in Argentina its audience was split between what Rosselli (1990: 168) calls 'fashionable' mostly non-Italian, oligarchic audience, which frequented large opera houses such as the Colón or the Teatro Argentino La Plata, and a more popular, 'almost wholly Italian' scene based in small theatres around Buenos Aires. The latter had died out by the 1950s, undoubtedly because of new technology such as cinemas, radio and television, but also according to Roselli in part because the Italian migrants who had brought opera with them from the mid$19^{\text {th }}$ Century onwards had assimilated more into popular Argentine identities by that time. Even when the very grand building in which it is now housed was in the last stages of construction in 1903, discussions in the National House of Congress over how to finance the remaining costs included what John Hodge calls a 'vituperative harangue' from Deputy Pastor Lacasa, who 'sneered at the bond issues, opera houses in general and all public monuments, painting them as the results of a conspiracy of the rich to amuse themselves at the expense of the poor' (1979: 250). The Radical Hipólito Yrigoyen was said to have attended as little as possible when he was President in 1916-22 (Rosselli 1990). 
That said, as Claudio Benzecry $(2011,2014)$ has pointed out, plebeian publics have always attended the Colón, especially in its early years. They heard opera performances from the upper floors which house around $20 \%$ of the audience. Entry tickets to these spaces, particularly those that were standing only, were and continue to be relatively cheap, certainly in comparison with the tickets for the boxes but also in comparison with tickets for other attractions such as football games (Benzecry 2011). Middle class opera fans continue to attend the 'paraíso', or 'paradise' floor closest to the ceiling, and take advantage of the excellent acoustics, the beautiful painting and the light up there; although the immediate surroundings such as the chairs are not nearly as luxurious as the boxes lower down, and they are kept apart from the wealthy patrons. Benzecry argues that there has always been a tension in the Colón between elite understandings of opera as a civilizing process for the nation modelled on modern European (white) high culture and a more democratic character of access in actual fact. Even Juan Domingo and Eva Perón recognised the importance of the Colón and attended regularly on the two national holidays of May $25^{\text {th }}$ and July $9^{\text {th }}$, fully respecting the gala traditions as other presidents and their wives had done (Benzecry 2011; Benzecry 2014).

My informants felt very strongly that the Colón was a crucial public good that should be preserved, even though it was utterly associated with elite understandings of high culture, especially associated with white European and colonialist modernity. The workers referred to it as national patrimony, both architecturally and culturally, arguing that it symbolised excellence. This is literally true: a common practice in Argentina when someone does something very well is to call out 'IAl Colón!', something that audiences often did after 
particularly good performances in the demonstrations described at the beginning of this article. $^{13}$

Beyond that, some who had been employed by the theatre since the mid-1980s spoke warmly of a time when it explicitly reached out to more popular audiences, for example when, in contrast to the elitist understanding of the Colón held by military regime of 197683, the director of the time:

'realised rapidly that the theatre had to win over the general public. So, one of his biggest merits was to take the theatre out onto the streets. I remember - I started in this period - we had a really exhausting work regime, because we worked the whole week in the theatre and at the weekends we held shows in [public parks in Buenos Aires], or on the 9 de Julio [Avenue]. ... All of a sudden there was a kind of cultural effervescence.... At that time there was still a notion that culture was an investment in itself, that it did not necessarily have to produce economic return.'

[MP 04.03.2009]

At one demonstration when one of the speeches referred to opera's elitism, a singer nearing retirement pointed out that her children had received free tickets to the opera through their school. Her point was that the opera had the potential to be an institution that reached beyond the classic opera audience of the haute bourgeoisie. A commonly repeated phrase during both public meetings, conversations and interviews, was that the Colón should produce 'rédito social', i.e. a kind of social interest or profit as opposed to simply 'rédito económico'. The workers wanted the opera to play a significant role in the wider local community; although at the same time they were slightly appalled at the idea of

\footnotetext{
${ }^{13}$ See also 'Argentine opera house Teatro Colón reopens' BBC News video, interview with Opera student (03.15) http://www.bbc.co.uk/news/10273272 Retrieved 12 January 2012
} 
putting on performances of more popular events such as Tango shows or pop concerts. They felt these to be inappropriate cultural forms for an opera house, even if in practice they are far more closely associated with working class culture than opera is ${ }^{14}$. That said, Arlene Dávila (Dávila 2012) has traced how the recent emphasis on tango within Buenos Aires cultural policy is rather more connected with the promotion of tourism than with support for local cultural expression. The workers attributed the idea of the popularisation of the use of the building through such events to Mauricio Macri in particular, arguing that he viewed the Colón building in much the same way as he had viewed the Boca stadium when he was in charge there, namely as a space to make money.

There was thus a basic incompatibility between the visions of the mobilised workers and those of the management about the purpose of this kind of cultural institution. The workers characterised this incompatibility as the management desiring to make the Colón into a profitable business. Using a familiar logic of political rhetoric they would at times imply that this was for reasons of personal gain through corruption; at other times they would attribute it simply to a neoliberal outlook. The phrase 'sala de alquiler' came to stand in for a set of cultural policies of sub-contracting and out-sourcing production, and seeking earning opportunities outside of the defined cultural activity, such as through the rental of retail space or putting on more obviously popular spectacles. In short order, the specifics of such potential policies did not need to be articulated in demonstration speeches and assemblies, since everyone knew what 'turning the Colón into a sala de alquiler' meant.

\footnotetext{
${ }^{14}$ See Archetti (1999) and Collier (1997) for discussions of the association of tango with working class masculine culture, in its early years.
} 
Sujatha Fernandes (2013) has traced a trajectory in Latin American states' approaches to cultural policy, from state sponsorship to the resignification of culture as a commodity, which she argues happened in Venezuela under the neoliberal government of Carlos Andres Pérez in the 1990s. George Yúdice argued that this resignification has gone beyond merely viewing culture as commodity to viewing culture as resource: 'culture is increasingly wielded as a resource for both sociopolitical and economic amelioration ... Art has completely folded into an expanded conception of culture that can solve problems, including job creation. Its purpose is to lend a hand in the reduction of expenditures and at the same time help maintain the level of state intervention for the stability of capitalism'. As a result, culture is justified on the basis of utilitarian arguments about the role of culture as a means to the promotion of various social, political and economic ends, rather than an end in itself, 'culture is no longer experienced, valued, or understood as transcendent.' (Yùdice 2003: 912). This shift implies a range of 'neoliberal' approaches to cultural policy, including both those which focus on economic profit and those which emphasise social utility. The management of the Colón and the government of the City of Buenos Aires could by this argument certainly be said to have a neoliberal approach to cultural policy - at least in the workers' eyes - insofar as they appeared to focus primarily on the utility of culture, especially in terms of economic return. Thus, for example, tango is promoted and valued particularly because of the foreign investment it can bring in through the tourist industry rather than the social return it might provide to local residents (Dávila 2012).

Such a politics fits with the approach to government in Buenos Aires including outside of cultural matters. Macri's political rhetoric has consistently promoted 'efficient' government. He draws on his past as someone widely thought to be a successful President of Boca 
Juniors to present himself as a rational businessman who pulled Boca out of bankruptcy through a mixture of good governance, rational decisions and effective use of market opportunities, and who can do the same for the city of Buenos Aires (Forment 2007). His electoral material contrasts this approach to 'Tammany hall cronyism' (Forment 2007: 108) and the squandering of public funds on 'ñoquis' (state employees who draw their salary but do not work $)^{15}$. An article from 2010 in the magazine Opera Now applied such a political perspective to the workers of the Colón, saying 'the Colón, like many Italian opera houses, has an oversupply of workers. Because of strong unions, they can't be fired, and they strike at any whiff or threat to their job or (excessive) (sic.) benefits. ${ }^{16}$

Of course, one might argue that the best way of assessing whether a cultural institution is acting efficiently as a public good would be through market mechanisms: can a majority of the population gain access to the good and do they want to? Such an assessment might not mean that opera is completely starved of funds: in March 2011 the Colón hosted Plácido Domingo, a figure who appeals to both elite and popular opera audiences. In fact, he became involved in the worker-management dispute of the time (a development of the dispute that is the main focus of this article, involving the same protagonists). The mobilised workers were delighted that he met with and, according to them, sided with them at a press conference he gave. Because they were on strike at the time they refused to allow him to sing on the stage, however, they allowed the orchestra to play for a free concert that he gave on the Avenida 9 de Julio and for which 20,000 free tickets were distributed. ${ }^{17}$

\footnotetext{
${ }^{15}$ The term ñoqui is used because people traditionally eat gnocchi at the end of the month, and the ñoqui employees only come into work at the end of the month in order to collect their salary.

${ }^{16}$ Karyl Charna Lynn, 'Restoration Drama: The Teatro Colón' Opera Now September-October 2010. p. 30

${ }^{17}$ See http://www.youtube.com/watch?v= uVC9dPjsVs\&feature=endscreen\&NR=1 for the press conference. Domingo made statements of broad support for the workers and urged both sides to come to agreement.
} 
Although such an event underlined the popularity of some opera, my informants did not want their opera house to only stage such obviously popular events. They argued instead for a diversity of cultural provision, including repertoire opera pieces of much more limited appeal.

The Colón dispute as a labour dispute

For the mobilised workers, their dispute with the theatre management was also clearly a dispute about labour conditions within the institution itself; it was about their 'fuentes de trabajo', their jobs. Several factors coalesced at the beginning of 2009. The refurbishment itself bothered the workers, including musicians, singers and dancers, because in the mean time they had to rehearse, build scenery etc., and perform in inadequate spaces, and there was no clear time frame or budget for its completion. It also appeared to be an excuse or opportunity for the theatre management to attempt to reduce the number of employees on the books of the Colón.

In March 2009 the new Director, Pedro Pablo Garcia Caffi, announced that he proposed to reduce the number of employees from around 1200 to $800^{18}$. A list was produced of 278 named permanent employees who would be transferred to other municipal jobs, while 92 contracted employees were told they would be moved to employment in the health sector. The 278 had to be transferred rather than fired because as state employees the majority enjoyed 'estabilidad laboral', that is permanence of employment, a provision protected by the Argentine constitution. Perhaps unsurprisingly some of the most active union delegates

\footnotetext{
${ }^{18}$ His success in this is mentioned approvingly on the official Teatro Colón website, as part of a modernization process.
} 
were on the list of those to be transferred, even though as members of a union junta interna they are supposed to be protected by law from being removed from their employment. The announcement of the transferrals was what provoked the most widelyattended series of assemblies and mobilisations, and the announcement of a 'state of permanent assembly', which is a period of regular assemblies and other mobilisations.

Those in the most vulnerable position with respect to transferral were employees on short term contracts. As a form of state employment, such contracts are held by some - especially in ATE - to be unconstitutional. The 1990s saw a proliferation of different categories of temporarily contracted state workers, as there was a freeze in the recruitment of permanent staff. There is now a wealth of forms of contracted work in the state, at varying levels of "precariousness", to use ATE's term. At the more precarious end is the contract for provision of services, where the worker has the fiscal category of self-employed, and where contracts usually last for a year, but can be for 6 months, 3 months or even one month. These were modelled on contracts common in the private sector and known colloquially as 'contratos de basura', garbage contracts. At the other end of the spectrum is the category of the planta transitoria, which denotes a regimen where workers have almost all of the labor rights of permanent workers, minus stability. ATE in particular have brought the issue of short term contracts to the fore of their political activity, arguing that it is a kind of informality, which they call 'trabajo en negro' ${ }^{19}$, and that it is anti-constitutional (Lazar 2012). One of the problems for employees on short term contracts is that they are often not paid their salary while the renewal of their contract is being negotiated, usually at the end

\footnotetext{
${ }^{19}$ A near English translation might be 'cash in hand work'. The phrase literally means 'work in the black'. Formally registered work is called trabajo en blanco, literally work that is 'in the white'. The association of black with illegitimacy is one indication of the way that racist metaphors underlie cultural life.
} 
of the year. Short term Colón employees were in a very vulnerable position given that the theatre was not functioning at full strength.

In the meantime, a third aspect of the dispute was the treatment of those employees of retirement age; whom the theatre management attempted to force to retire by the expedient of simply not paying their salaries for several months at the beginning of the year. Again, their position was made more difficult because of the theatre's lack of functioning, but they argued that they simply could not afford to retire. In the now rather distant past, the state retirement pension had been set at $82 \%$ of final salary, and if the active employees' salary rose, pensions rose at the same rate. This is known as the ' $82 \%$ móvil', and its return was a common demand of ATE demonstrations. However, with Carlos Menem's reforms this was removed, and employees only received around $40-55 \%$ of their salary as a pension. Every Wednesday for two decades now, pensioners have staged a demonstration at the Congress building demanding the $82 \%$ móvil $^{20}$. The situation was further compounded by an additional innovation in the 1990s, which was the increased use of payment of part of state salaries 'en negro', as bonuses for different categories but which are not subject to pension contributions from either employee or employer. Thus, as Ochoa said, 'they paid us our salary en negro, which doesn't have [pension] contributions [from the employer], so when I want to retire, I can't retire, because I don't have the contributions' [RO 25.06.2009]. The question of being paid part of a salary 'en negro' and its effect on retirement pensions was another aspect of labour precariousness (or informality) that was at the heart of ATE concerns about state employment beyond the Colón (Lazar 2012).

\footnotetext{
${ }^{20}$ In June 2011, the pensioners demonstrated for the $1000^{\text {th }}$ time. Marcos Wolman, 'Los mil miércoles de los jubilados y las principales reivindicaciones' CTA Capital news release, 10.05.2011. Available at http://ctacapital.org.ar/spip.php?article238. Retrieved 08.03.2012
} 
Because of the way that their salary was constructed partially 'en negro', many Colón employees were retiring on around $50 \%$ of their actual salaries, according to my informants. Although this amount might seem generous in European and North American terms, they pointed out that state salaries are very low, and that the most usual outgoing with respect to housing is not a mortgage that can be paid off before retirement but 'expensas', namely the ongoing expenses that owners of apartments must pay for the upkeep of an apartment building. An ATE delegate from another institution also argued that in a country where high inflation is normal and hyper-inflation an experience within living memory, pensions need to start off high in order to protect their value. To this one might add the very recent experience of massive currency devaluation as another source of uncertainty with respect to purchasing power of a pension. Finally, my informants also simply pointed out that people had achieved a certain standard of living that they felt they should be able to maintain.

In the face of these points of conflict, the mobilised workers developed a series of strategies. In particular, they focussed on flamboyant demonstrations that captured media attention, exploiting and heightening the performative nature of protest. The weekly events on the Avenida de Mayo were literally performances; of dances and songs. Another demonstration involved a mock funeral for 'culture', where they carried a coffin labelled 'culture' on a funeral procession around the theatre, proclaiming its death as a result of the management attacks on the theatre. ${ }^{21}$ In the preparatory assemblies for 'culture's funeral',

\footnotetext{
${ }^{21}$ See photos at http://habituesdelteatrocolon.wordpress.com/2009/06/27/viene-el-cortejo/ Retrieved 12 January 2012. Also 'Un funeral en la puerta del Teatro Colón' La Nacion, 25th June, 2009. 
Máximo Parpagnoli described this protest as an 'escrache', using the term originally coined to describe the artistic protests organised by H.I.J.O.S. ${ }^{22}$ against members of the dictatorial regime (Benegas 2013; Kaiser 2002; Taylor 2003). Other tactics included specific actions to gain the attention of the media, such as when some of the workers entered the Colón building while it was closed and took photographs of the refurbishment activities which they distributed by email and via the blog for the 'habitues del teatro colon' ${ }^{23}$. Newspapers reported this as a break in and violent takeover of the premises ${ }^{24}$, but the workers were able to publicise their concerns about the destructive activities taking place.

They also held press conferences at key moments of the dispute and music festivals to display and encourage solidarity with the workers; and they advertised events and news about the dispute on the 'habitues' blog. All these strategies were combined with more conventional demonstrations and mobilisations, such as workers' assemblies and participation at the head of general ATE marches. Some of the unionists saw their particular conflict as very linked to other ongoing labour disputes within the public sector: for example, at one ATE plenary assembly, Jose Piazza argued that the attack on the Colón was an attack on national patrimony similar to the national government's 'attack' on INDEC (Instituto Nacional de Estadisticas y Censos), the government office of national statistics. By this, he attached his own labour conflict to the most acute one taking place within state

\footnotetext{
${ }^{22}$ H.I.J.O.S. is Hijos e Hijas por la Identidad y la Justicia contra el Olvido y el Silencio - Sons and Daughters for Identity and Justice and against Forgetting and Silence, an organisation founded in 1995 that brings together the children of parents who were disappeared by the military regime of 1976-83.

${ }^{23}$ See http://habituesdelteatrocolon.wordpress.com/; the photos referred to here are available at http://habituesdelteatrocolon.wordpress.com/2009/04/02/fotos-del-31-de-marzo/ although at the time anonymous postings of photos of the interior of the theatre were common on habitués. Retrieved 12 January 2012

${ }^{24}$ See for example 'García Caffi denunció vandalismo en el Colón' La Nación 1 April 2009 http://www.lanacion.com.ar/1113959-garcia-caffi-denuncio-vandalismo-en-el-colon Retrieved 12 January 2012
} 
employment at the time and argued that both arose from neoliberal political positions that were 'destroying what we are as argentines' ${ }^{25}$ Here, he made no distinction between the city government regime of Mauricio Macri and the national regime of President Cristina Fernandez de Kirchner, despite the fact that they are from two opposing political parties.

Alongside the strategy of mobilisation, in the middle of 2009 the workers began a twopronged legal process. At an assembly in La Nube, a technical workshop in the district of Palermo where stage sets were being constructed, a lawyer was invited to outline the possibilities for legal action that the assembly could take. He told them that they could bring legal actions on two fronts: first, on the basis of the procedure for reducing the number of personnel not having been conducted in precise accordance with the law, and second, regarding the refurbishment of the building itself. As 'national patrimony', modifications need what he called 'a mountain of requirements' which hadn't been met in their totality in the current refurbishment. So the legal strategy could combine the labour issue with the cultural issue, or the assembly could decide to go ahead with the labour question on its own. He thought that pursuing the cultural question might be helpful given wider societal prejudices against public employees. The assembly had to decide whether to pursue one or both strategies, and if so, how they proposed to pay. Some felt that they union ought to provide legal representation, especially on the labour matter, but ultimately they voted to go ahead with both legal actions, and they agreed to raise quotas for both from among those at the assembly and whom they could approach over the following few days.

${ }^{25}$ Field notes 9.2.2009. 
The legal case about the transferrals and forced retirements was based on an argument that the management had not followed correct consultation procedures, by not talking with properly elected workers' representatives. According to my informants, the management had been talking more informally with the other union operating in the theatre, SUTECBA, negotiating with them over who would be transferred and where. Those of my interviewees who were members of ATE characterised SUTECBA as basically in the pockets of the employers, and more vehemently, 'ladrones, asesinos' (thieves and murderers), motivated by 'an excessive ambition for power, fundamentally economic power - that's to say, to make money.'

Within the workers' assemblies of the Colón, there were significant connections between SUTECBA delegates - usually those from electoral lists to the left of the dominant one - and ATE delegates and affiliates. However, the central SUTECBA leadership certainly wanted a speedy resolution and were prepared to accept the transferrals. SUTECBA has a larger number of affiliates in the theatre than $\mathrm{ATE}^{26}$. But ATE delegates consistently told me a story of attempting to be active on behalf of the workers within SUTECBA but failing because of resistance from central leadership. When they got the opportunity in the 1990s to affiliate to a different union, they jumped at the chance; but retained good relationships with more radical sectors of SUTECBA.

Work or art?

\footnotetext{
${ }^{26}$ See above, note 3 .
} 
The Colón workers were a group of people who attempted to defend themselves by defining themselves as workers with demands not too different from those of other state employees. Yet they needed to articulate what was a fairly elitist vision of cultural activity, and argue for it as a general public good. On top of that, they faced another problem, that of whether the workers of the Colón felt themselves to be workers or artists. Part of the story of the switch from SUTECBA to ATE as recounted to me by ATE delegates is that of an initiative led by Máximo Parpagnoli in the late 1980s under the SUTECBA umbrella which is known as the 'intercuerpos' commission. This was an attempt to bring together the different corps of workers within the opera house: dancers, singers, orchestra musicians and technical personnel within a unified trade union organisation. Previously the different corps had negotiated separately with the management; and SUTECBA continues to affiliate mostly technical personnel. However, at the time, a group of technicians and artists felt that the theatre relied equally on both the artistic and the technical personnel. My interviewees continued to believe quite passionately in the importance of such solidarity, it being a strongly held philosophical point about the nature of the theatre and of their relationship to it: 'if it doesn't act as an organised and productive community, the theatre doesn't have a reason for being'. [MP 04.03.2009]

But the organisation of the intercuerpos commission was difficult, and exposed tensions about identity that are still important today. It was very difficult to get the artists to see themselves as workers and as part of the same enterprise as the technicians and other theatre employees. Part of the problem was that the artists had won their place through a public competition recognising their excellence, and this pulled against their self-perception as workers. In contrast, for Parpagnoli, 'Before being an artist, you're a worker, you're a 
laborer.' [MP 04.03.2009] Although probably the most eloquent on this topic, Parpagnoli was not alone in emphasising the importance of the theatre as collective endeavour, and the worker-based identity of the theatre's employees.

The tension between an identity as an artist and one as a worker had an impact upon the possibilities for (unionised) mobilisation; as Jose Piazza summarised it, 'the artists don't understand about unions, about unionism or anything' [JP 16.03.2009]. That said, although the mobilised workers in 2009 did not include very large numbers of artists, there were some key artists who did take part: singers, musicians and the dancers who participated in the events. Piazza himself, who led the ATE junta interna, is a trumpeter. Others straddled artistic and technical areas: Parpagnoli was the staff photographer; Sara Tonazzi was a scenery painter. They all held in common a feeling that the Colón was a special place to work, a place of excellence, of specificity. For that reason they resisted fiercely the idea that they could simply be transferred from a job at the theatre to another job in local government administration, and pointed to the absurdity of a trumpeter moving to work at a hospital, for example. It is possible that those working in less specialised areas were less concerned about a transferral. However, frequently people pointed out to me that even seemingly transferable skills were in fact specialised, as with maintenance for example, given the importance of the hall's acoustics.

In practice, what motivated most people to mobilise was their identity as a member of the Colón itself. In the assemblies and demonstrations, no distinction was made between SUTECBA, ATE or unaffiliated workers, despite the profound differences in politics and tactics between SUTECBA and ATE. A great deal of emphasis was placed upon the status of 
the assembly grouping as a 'workers' assembly' of the Colón. This blurred the distinctions between the different political affiliations, which enabled the mobilisation of greater numbers of people, but also reflected the reality of a decoupling of personal feelings of identity as a worker from one's membership of a specific union. The theatre itself was the most important workers' collectivity. Informants argued that working for the theatre was a source of considerable pride and self-esteem, because they had reached the pinnacle of artistic achievement by coming to work there. But it was also a source of collective identification. Ricardo Ochoa spoke to me of the emotional connection for him between the protest when the workers held a mock funeral for 'culture' in June 2009 and a time when Colón workers had shown such commitment to the theatre that they wanted their ashes to be buried there, or their coffin to be taken around the building:

'So, when I was carrying that coffin yesterday, once we started to walk, I said to myself 'it can't be, I'm here, symbolically protesting the death of culture, and I actually did this for real with a compañero, Luis. He had asked for us to carry his coffin around the Colón when he died, just because he felt part of the theatre.' I say, the Colón isn't mine, it's not my work place, my pigeonhole in an office. I work here, I feel an integral part of it but I don't own it. It belongs to all of us. And there was a guy who wanted his ashes scattered here, or his body taken round when he died. It's so strong because that guy felt something for the place.'

[RO 25.06.2009]

Thus, tensions about identities as worker or artist were to some extent resolved through the creation of an identity as part of the theatre itself; hence the frequently expressed emotion about the potential destruction of the fabric of the building and the emphasis on the theatre 
as national patrimony. Some linked their pride as part of such a special and important institution back to the broad terms of their dispute with the management over the changing of model from teatro de producción to sala de alquiler and labour conditions within the theatre as exposed in the dispute over forced retirements and also short term contract employment.

For them, one of the main problems with the management strategy for reduction in personnel was the fact that it was leading to the gradual loss of a repository of experiential knowledge within the body of workers. By replacing retired workers with employees on short term contracts, and then even forcing more workers to retire, the management was not seeing to the gradual renewal of personnel. Since the Colón is or was a repertory theatre, turnover of personnel should in this view be constant but gradual; Parpagnoli said that at one point it was around $10 \%$ a year only. When staff turnover is gradual, the older workers - be they singers or technicians - can educate the newer people in the techniques of any given production that is part of the Theatre's repertoire. That way there is no need to reinvent the wheel for each new staging of a production, and the expertise passes from generation to generation.

However, with most new employment contracts being short term, such a passing on of knowledge is ruptured; and by forcing the retirement of older employees the possibility for a gradual accretion of skills through intergenerational transfer disappears completely. By this logic, the destruction of the teatro de producción is happening through employment policy, because in time in-house production will no longer be possible since the local knowledge will no longer exist. 


\section{Conclusions}

Although the Colón is clearly an extremely specialised institution, many of the issues I have discussed above are pertinent to state employment in $21^{\text {st }}$ Century Argentina more generally. Parpagnoli made this point explicitly, when he explained to me the connections between 'la crisis institucional del teatro' and 'la herencia del neoliberalismo' (the institutional crisis of the theatre and the legacy of neoliberalism):

'That is, payment of salaries 'en negro', the impossibility of a dignified retirement, the rise of the 'garbage contract' (contrato basura) as a means of covering standard jobs, the concept that if culture does not give an economic return it's not worth it, that's to say the liberal concept that it has to be efficient from the economic point of view; all that has begun to choke off the model of production and of stable corps [of artists]. And, independently, added to that is the corruption internal to the theatre'. [MP 04.03.2009]

The move from employment based on permanent contracts to increased use of short term contracts is common across municipal and national government, although the national government has recently made moves to redress the balance somewhat. The implications for intergenerational transfer of knowledge and solidarity within the workplace are unclear. If the worst prognoses of the Colón workers are correct, then the theatre itself as well as the state administrations that develop in the same way will likely become more expensive and less efficient. On the other hand, perhaps this is simply conservatism, a desire for things not to change. There is a kind of absurdity, though, in deeming it efficient to reduce the roll of 
employees in one municipal institution by simply moving them to another where their highly specialised skills are irrelevant.

The situation of pensioners is another common element across state employment. Where part of the salary is paid in bonuses for good performance, seniority, or simply because it has been negotiated by the union as a means of providing a salary increase, it is not liable for employer's contributions to the employee's pension. Across national and local government, ATE activists argued that this payment 'en negro' damages their future pension. It means that the pensioner gets less than their due because it is only calculated on the basis of the part of the salary that is 'en blanco' ('in the white', i.e. formally registered). And the value of that formal part of the salary has been decreasing for years now. Activists saw both issues as questions of the precariousness or informality of state employment, against the constitutional protection of stability (see Lazar 2012). Informalization of state employment understood in these terms is a key problem for all of the unions of state employees, although they deal with it differently, through demonstrations or backstage negotiations. I suspect it is a problem that is not confined to Argentina and poorer countries, as some of the mobilisations of precariously employed young workers in Spain and Portugal testify. In the UK, increasing use of internships in state-run or state-subsidised institutions, especially cultural institutions, indicates a similar move towards informalisation. Further, subcontracting and outsourcing of many state functions means that precariously employed workers nominally in the private sector are performing public sector work.

Whether the City Government of Buenos Aires has the capacity to support a fullyfunctioning opera house, and whether it should be directing its energies that way expose a 
more general argument about cultural policy and the role of the market in the public sector. If, as Forment (2007) argues, Macri's prime concern is the 'efficiency' of the Buenos Aires administration, then that efficiency is both achieved and measured by means of market competition rather than considerations of social good - 'rédito económico' as opposed to 'rédito social'. The move to legitimate investment in culture on the basis of utility is common across many parts of the world, certainly the Americas (Yùdice 2003), and shows little sign of abating. The experience of the Colón shows that in the contemporary environment of market-oriented approaches to government understood in specific, 'neoliberal', ways, workers have to develop particular ways to protect their employment conditions. One is to participate in utility-based discourses about culture and argue in terms of social utility, or return, rather than culture as an end in itself as might have been the case in earlier decades.

That said, during interviews and public assemblies, demonstrations and so on, the workers often maintained a commitment to culture as transcendent. This combined with another aspect of their work to shape the ways they could protect their employment conditions, namely the nature of the product they produce as mostly immaterial (Hardt and Negri 2005). The Colón workers produce an opera and ballet season, which has both material (scenery, costume) and immaterial aspects. Their immaterial products are, among others, the affect of enjoyment among audiences, the moment of performance (music, song, dance), the pride of the workers as members of the Colón, even excellence itself. The kinds of mobilisation possible were in part dictated by the immaterial nature of the labour: for example the emphasis on attracting media interest through dramatic performance was logical for a group of workers whose product is dramatic performance. They were well 
aware of this, although they also conceptualised their events as part of a dramatic style of protest utilised by other Argentine social movements, especially those of young people.

The immaterial nature of the work did however create problems for worker mobilisation to protect employment conditions, because mobilisation specifically around notions of production was highly fragile. It was vulnerable to the artists' claim that they are not workers, which creates a division between the different groups of theatre employees. It was also vulnerable to the charge that mobilisation, for example through disruption of performances, is detrimental to the production of excellence as well as the desire to create art that is thought to be innate to the theatre and its personnel. This is of course a paradox faced by public sector workers more generally: when teachers and nurses strike they are often accused of working against the interests of those whom they are supposed to serve (i.e. the public), rather than working against the interests of their employers, because a strike by such categories of workers disrupts the production of affect, of care. Any labour dispute is tiring, and in September 2011, Máximo Parpagnoli recounted to me how he and the other leaders felt they had achieved some victories, but had not managed to protect all the jobs they had wanted to, despite the complex legal and political strategies they used. Their mobilisation had ebbed and flowed over 2009-11, and from the middle of 2011 onwards they entered a quiet period, since people were tired of constant demonstrations, assemblies and so on. The building had been re-opened in 2010 as part of the national bicentenary celebrations, but productions had not reached the quality or quantity that had been achieved in its heyday. On the other hand, neither had the total neoliberalisation or outsourcing that they feared occurred, so far. Their struggle for better 
working conditions continued, fighting specific conflicts as they arose and using the different strategies available to them. 


\section{References}

Archetti, Eduardo P.

1999 Masculinities : football, polo and the Tango in Argentina. Oxford: Berg.

Basso, Gustavo Jorge, Alberto M. Haedo, and Rafael Sanchez Quintana

2010 Preservation of the acoustical quality of the Teatro Colon of Buenos Aires. The Journal of the Acoustical Society of America 128(4):2275-2275.

Benegas, Diego

2013 Trabajar el barrio: el escrache como intervenciòn cultural. Acta Sociològica 60(enero-abril 2013):79-101.

Benzecry, Claudio

2011 The Opera Fanatic. Ethnography of an Obsession. Chicago: University of Chicago Press.

Benzecry, ClaudioE

2014 An opera house for the "Paris of South America": pathways to the institutionalization of high culture. Theory and Society 43(2):169-196.

Beranek, Leo

2004 Concert Halls and Opera Houses: Music, Acoustics, and Architecture. New York: SpringerVerlag.

Bourdieu, Pierre

1986 Distinction. A Social Critique of the Judgement of Taste. London: Routledge.

Collier, S., and K. Haas

1997 Tango!: the dance, the song, the story. London: Thames \& Hudson.

Dávila, A.M.

2012 Culture Works: Space, Value, and Mobility Across the Neoliberal Americas. New York: New York University Press.

Fernandes, Sujatha

2013 Cultural and Neoliberal rationalities in Post-Neoliberal Venezuela. In Neoliberalism, Interrupted. N. Postero and M. Goodale, eds. Pp. 53-72. California: Stanford University Press.

Forment, Carlos

2007 The Democratic Dribbler: Football Clubs, Neoliberal Globalization, and Buenos Aires' Municipal Election of 2003. Public Culture 19(1):85-116.

Gorelik, Adriàn

2011 Roles de la periferia. Buenos Aires: de ciudad expansiva a ciudad archipièlago. In Correspondencias. Arquitectura, ciudad, cultura. A. Gorelik, ed. Buenos Aires: SCA/Nobuko.

Guano, Emanuela

2002 Spectacles of Modernity: Transnational Imagination and Local Hegemonies in Neoliberal Buenos Aires. Cultural Anthropology 17(2):181-209.

2004 The Denial of Citizenship: "barbaric" Buenos Aires and the middle-class imaginary. City \& Society 16(1):69-97.

Hardt, Michael, and Antonio Negri

2005 Multitude. London: Hamish Hamilton.

Hodge, John E.

1979 The Construction of the Teatro Colon. The Americas 36(2):235-255.

Kaiser, Susana

2002 Escraches: demonstrations, communication and political memory in post-dictatorial Argentina. Media, Culture \& Society 24(4):499-516. 
Lazar, Sian

2012 A desire to formalize work? Comparing trade union strategies in Bolivia and Argentina. Anthropology of Work Review 33(1):15-24.

2015a Of autocracy and democracy, or discipline and anarchy: when organizational structure meets political ideology in Argentinean public sector trade unions.

2015b 'This is not a parade, it's a protest march'. Intertextuality, citation, and political action on the streets of Bolivia and Argentina. . American Anthropologist.

Rosselli, John

1990 The Opera Business and the Italian Immigrant Community in Latin America 1820-1930: The Example of Buenos Aires. Past \& Present (127):155-182.

Shever, Elana

2012 Resources for reform : oil and neoliberalism in Argentina. Stanford, California: Stanford University Press.

Svampa, M.

2008 Los Que Ganaron: La Vida en Los Countries y Barrios Privados. 2da edicion. Buenos Aires: Biblos.

Taylor, Diana

2003 The archive and the repertoire. Performing cultural memory in the Americas. Durham: Duke University Press.

Yùdice, George

2003 The Expediency of Culture. Uses of Culture in the Global Era. Durham: Duke University Press. 